\title{
Enrichment, Isolation and Some Properties of Methane-utilizing Bacteria
}

\author{
By R. WHITTENBURY, K. C. PHILLIPS AND J. F. WILKINSON \\ Department of General Microbiology, University of Edinburgh, \\ College of Agriculture, West Mains Road, Edinburgh EH $93 \mathrm{JG}$ \\ (Accepted for publication I6 January 1970)
}

\begin{abstract}
SUMMARY
More than I00 Gram-negative, strictly aerobic, methane-utilizing bacteria were isolated. All used only methane and methanol of the substrates tested for growth. The organisms were classified into five groups on the basis of morphology, fine structure, and type of resting stage formed (exospores and different types of cysts) and into subgroups on other properties. Methods of enrichment, isolation and culture are described.
\end{abstract}

\section{INTRODUCTION}

The existence of methane-oxidizing bacteria has been known for many years (see Leadbetter \& Foster, 1958) but attempts to isolate them in pure culture have generally been unsuccessful. Dworkin \& Foster (I956) and Leadbetter \& Foster (I958) isolated a number of methane-utilizing organisms and considered them all to be variants of the one species, Pseudomonas methanica. Two more species have since been isolated, a rod, Methanomonas methanooxidans (Brown, Strawinski \& McCleskey, 1964) and a coccus, Methylococcus capsulatus (Foster \& Davis, 1966). All three species were Gram-negative aerobes utilizing only methane and methanol as combined carbon and energy sources. Other reports of methane-oxidizing bacteria have been too brief to indicate whether they were new species or strains of known species. Reports of Grampositive bacteria provide no evidence of methane utilization in pure culture and generally mention the difficulty of maintaining the organisms on mineral salts media and methane, with one exception (Perry, I968). This organism, a strain of Brevibacterium, grew on all $n$-alkanes tested $\left(C_{1}\right.$ to $\left.C_{22}\right)$ and the disappearance of methane during growth was measured. Some reports relate the difficulties of obtaining pure cultures and describe results of studies on methane oxidation by mixed cultures (for instance, Vary \& Johnson, 1967).

The problems encountered in the isolation and culture of methane-oxidizing bacteria and the lack of cultures available for study, prompted the investigation we report here. Simple methods of enrichment, isolation and culture of methane utilizers, some of which are unique, are described.

\section{METHODS}

Media. Two basal media were routinely used and differed only in the nitrogen source added. They both contained in distilled water $(\%, \mathrm{w} / \mathrm{v}): \mathrm{MgSO}_{4} \cdot 7 \mathrm{H}_{2} \mathrm{O}, \mathrm{O} \cdot \mathrm{I}$; $\mathrm{CaCl}_{2}, 0.02$; sequestrene iron complex (Geigy, Johnsons of Hendon, Ltd.), 0.0004; 
either $\mathrm{NH}_{4} \mathrm{Cl}, 0.05$ (ammonium mineral salts-AMS); or $\mathrm{KNO}_{3}, 0 . \mathrm{I}$ (nitrate mineral salts-NMS); agar if added, I.25. Trace element solution (Pfennig, I962), 0.05\% (v/v) was added and the $\mathrm{pH}$ value of the media adjusted to 6.8 before autoclaving. Finally, $2 \mathrm{ml}$. of a sterile phosphate buffer solution (a mixture of $\mathrm{KH}_{2} \mathrm{PO}_{4}$ and $\mathrm{Na}_{2} \mathrm{HPO}_{4} . \mathrm{I}_{2} \mathrm{H}_{2} \mathrm{O} ; \mathrm{I} 5 \mathrm{~g}$. in $300 \mathrm{ml}$. distilled water, $\mathrm{pH}$ value $6 \cdot 8$ ) was added to media cooled to $60^{\circ}$.

Maintenance of cultures. Organisms were subcultured every 2 weeks on NMS or AMS agar slopes in tubes (plugged with cotton-wool) and incubated either in glass desiccators or bucket-shaped 'Tupperware' polythene containers (about 5 1. capacity) which had lids with airtight seals and, in the lids, small ports sealed with airtight caps. Desiccators were partially evacuated and filled with methane from a football bladder to give an approximate mixture of methane to air 30:70 under slightly less than atmospheric pressure. Polythene containers were gassed with methane by squirting a football bladder full (about 2 1.) through the ports in the lids, the final mixture of methane to air ranging from 30:70 to 50:50. Incubation was at $30^{\circ}$. Many cultures survived in these containers for 3 months at $4^{\circ}$, but frequently became contaminated with fungi as occasionally were cultures transferred at 2-weekly intervals.

The high humidity which developed in the enclosed containers stimulated fungal spores present in the unsterile atmosphere to germinate and grow on the inside surfaces of the containers and on the tube racks. Cultures incubated in containers in this state were frequently contaminated with fungi. Microscopical examination of cotton-wool plugs in culture tubes at intervals revealed that fungal mycelia grew on the outer top surface of the plugs and gradually penetrated down to the underside surface of the plugs in the tubes, where they released spores into the culture atmospheres. The spores subsequently contaminated the bacterial culture. This problem was overcome by $(a)$ swabbing out the container and the tube racks with ethanol between transfers, and (b) maintaining a duplicate set of cultures. Cleaning the containers regularly with ethanol reduced fungal contamination to an infrequent occurrence. Replacement of contaminated cultures with pure cultures from the duplicate set dispensed with the problem of having to purify the contaminated cultures. Liquid media were usually dispensed into conical flasks (generally $250 \mathrm{ml}$. narrow-necked Quickfit flasks, I9/26). After inoculation, cotton-wool plugs were replaced by 'Suba-seal' caps. Tubes and 'Universal' vials were also used.

For stoichiometric and bacterial dry weight determinations methane content was reduced to a ratio of methane to oxygen (in air) $I: 2$ or $I: 4$.

Screw-cap bottles of $250 \mathrm{ml}$. capacity were used in growth yield experiments. 'Subaseal' caps were fitted, methane inserted and metal caps screwed tightly over the 'Suba-seal' caps. Methane loss from these bottles was less than $1.0 \%$ of that added (after a week).

In all sealed cultures, medium usually occupied $20 \%$ of the container volume and the methane to oxygen (in air) ratio was usually $2: \mathrm{I}$. Air was not withdrawn before inserting methane by syringe so growth began at about $\mathrm{I} \cdot 4$ atmospheres pressure. Air-lift fermenters, stirred batch systems and conventional continuous culture vessels were adapted for use with methane. Tubing and stoppers were of silicone rubber as red rubber released toxic substances when in contact with liquid medium. As silicone rubber is permeable to methane, silicone rubber tubing was used to sleeve glass tubes together leaving as small an area as possible of silicone rubber in direct contact with 
methane. Losses of methane from these systems during experiments involving measurements of gas utilization were less than $\mathrm{r} \cdot 0 \%(\mathrm{v} / \mathrm{v})$. Closed-circuit systems were used in many cases, using aspirators as gas reservoirs and Watson-Marlow H.F. flow inducers as circulation pumps. Sampling devices, for both liquid and gas phases, were made from syringes inserted into silicone rubber bungs. All such systems were operated for long periods without contamination.

Routine production of large amounts of batch culture. A 51 . Quickfit culture vessel, with a 5-port lid, containing $200 \mathrm{ml}$. liquid medium and $20 \mathrm{ml}$. inoculum was stirred magnetically at $30^{\circ}$. Two of the ports were sealed with 'Suba-seal' caps. The initial inoculum was pipetted through one of these ports. A third port was fitted with a glass stopcock which was connected with silicone rubber tubing to a medium reservoir. A fourth port was fitted with a glass tube to which was attached a football bladder containing 21 . methane. Methane was sterilized on entering the vessel by a cotton-wool filter in the glass tube. The centre port was fitted with a stirrer gland converted to a siphon of adjustable depth. After $24 \mathrm{hr}$ the culture was harvested aseptically by siphon leaving about $20 \mathrm{ml}$. behind to inoculate fresh medium transferred from the medium reservoir by peristaltic pump after flushing out the vessel with sterile air. Methane was added as before. Batteries of such systems were set up in a hot room.

Inocula. Inocula were taken either from 2-day-old slope cultures or, when many vessels were to be inoculated with the one strain, from $20 \mathrm{ml}$. flasks containing $5 \mathrm{ml}$. liquid culture (plugged with cotton-wool) incubated in desiccators.

Growth on methanol and other substrates. Conventional methods were used except when growth yields and changes in the culture atmosphere were being determined when sealed systems were used.

Slide cultures. Molten agar medium was poured on to sterile glass slides and a sterile coverslip dropped on to the molten agar to cast a flat surface. The coverslip was removed when the agar solidified and the surface inoculated by streaking. After the surface had dried, a central channel of agar was removed and a coverslip placed on the agar. The slide cultures were incubated in a polythene container to which methane was added. Growth of the cultures was observed under a phase-contrast microscope at intervals.

Analyses. A katharometer isothermal head on a Pye series 104 gas chromatograph was used to analyse for $\mathrm{CH}_{4}, \mathrm{CO}_{2}, \mathrm{O}_{2}$ and $\mathrm{N}_{2}$. Gas samples in which the content of $\mathrm{CH}_{4}$ and $\mathrm{CO}_{2}$ were being compared, were passed through a $5 \mathrm{ft}$ column containing 80 to roo mesh silicagel at $85^{\circ}$, and samples in which $\mathrm{CH}_{4}, \mathrm{O}_{2}$ and $\mathrm{N}_{2}$ were being compared, were passed through a $5 \mathrm{ft}$ column containing 60 to 80 mesh molecular sieve at $85^{\circ}$. Helium, the carrier gas, flowed at $60 \mathrm{ml} . / \mathrm{min}$. Signals were recorded on a Leeds and Northrup Speedomax ' $\mathrm{W}$ ' recorder. Samples ( $\mathrm{I} \cdot 0 \mathrm{ml}$.) were extracted and $0.5 \mathrm{ml}$. was inserted by syringe, or $0.5 \mathrm{ml}$. samples were removed from closed atmospheres by a gas sampling loop attached to the chromatograph. Changes which occurred in the composition of gas mixtures over stirred batch cultures were assayed at short intervals by the latter method.

Methane (when $\mathrm{O}_{2}, \mathrm{CO}_{2}$ and $\mathrm{H}_{2}$ were not being assayed), ethane, methanol, ethanol and acetaldehyde were assayed with a flame ionization detector on a Pye series-I04 gas chromatograph using a $5 \mathrm{ft}$ column packed with 'Phasepack $\mathrm{Q}$ ', treated with 'trimer' acid (Phase Separation Ltd., Flintshire), at $100^{\circ}$. Gas samples containing acetylene and ethylene were assayed on a $5 \mathrm{ft}$ column containing 'Phasepack $R$ ' at 
$100^{\circ}$. Nitrogen, the carrier gas, was flowed through both columns at $60 \mathrm{ml} . / \mathrm{min}$. Gas samples $(0.5 \mathrm{ml}$.) and liquid samples ( $1.0 \mu \mathrm{l}$.) were extracted and $0.2 \mathrm{ml}$. and $0.4 \mu \mathrm{l}$., respectively, inserted by syringe. Results were recorded on a Vitatron Manual Linear Recorder UR 402.

Gases. Methane, biologically produced, was obtained from Greater London Council, Mogden Works, Isleworth, Middlesex, and was used routinely. Methane and other gaseous $n$-alkanes of high purity were from Air Products Ltd. and Cambrian Chemicals Ltd. Natural gas, originating from the Sahara and from the North Sea, was from Air Products Ltd.

Reduction of acetylene. Batch cultures $(25 \mathrm{ml}$. in $250 \mathrm{ml}$. bottles sealed with a 'Suba-seal' cap and screw-capped) grown in AMS liquid medium, in which $\mathrm{NH}_{4} \mathrm{Cl}$ had been lowered to $0.01 \%(\mathrm{w} / \mathrm{v})$, under a methane-air mixture, were screened for ability to reduce acetylene to ethylene. When ammonium ion was no longer detectable, the cultures were flushed with helium and resealed with 'Suba-seal' caps. Helium (20 ml.) was withdrawn and gases $\left(28 \mathrm{ml}\right.$.) added $\left(\mathrm{O}_{2}\right.$, IO ml.; $\mathrm{CH}_{4}$, IO ml.; $\mathrm{N}_{2}, 4 \mathrm{ml}$.; $\mathrm{C}_{2} \mathrm{H}_{2}, 4 \mathrm{ml}$.). Metal caps were screwed over the seals and the stagnant cultures were incubated at $30^{\circ}$. Samples of gas were withdrawn at 7 and 14 days and analysed.

Assay of poly- $\beta$-hydroxybutyrate. The method of Law \& Slepecky (196I) was used. Nitrite estimation. The method of Rakestraw (1936) was used.

Incubation. Cultures were incubated either statically or in shaking incubators at 30,37 or $45^{\circ}$.

\section{RESULTS AND DISCUSSION}

\section{Enrichment and isolation}

Mud and water (from ponds, rivers, streams and ditches), and soil samples, obtained from the U.K., the European continent (France, Germany and Russia), North America, South America, East and North Africa and Egypt, were used as inocula. Approximately I g. was added to $25 \mathrm{ml}$. of AMS or NMS liquid medium in a $250 \mathrm{ml}$. bottle, which was sealed with a 'Suba-seal' cap and then injected with $20 \mathrm{ml}$. of methane. The enrichments were incubated statically at 30,45 and $55^{\circ}$. Turbidity, often accompanied by a pellicle, was taken to be presumptive evidence of the growth of methane-utilizers and usually appeared after 3 or 4 days.

Such cultures were serially diluted in sterile tap water and spread on to AMS or NMS agar plates which were incubated in a methane-air mixture in vacuum desiccators or polythene containers. The plates were examined at 3-day intervals over 3 to 4 weeks. Colonies which proved to be non-methane utilizing reached their maximum size in about 3 days. Methane-utilizing colonies began to appear after about 5 to 7 days and were frequently Io to Ioo-fold fewer in number than non-methane-utilizing colonies which presumably were using dissolved organic materials in the agar component of the medium; colonies, similar in size and number, appeared on duplicate plates incubated in the absence of methane. Under a plate microscope colonies which later proved to be composed of methane-utilizing organisms were opaque and on continued incubation increased in size over 2 to 3 weeks. Non-methane-utilizing colonies remained small and relatively transparent.

Isolation was most successful at the small colony stage $(0.2 \mathrm{~mm}$. diam.). With the aid of a plate microscope, colonies were transferred with a straight wire to AMS or NMS agar slopes, which were incubated for 2 weeks. The subsequent growth was 
streaked on to AMS or NMS agar plates, single colonies picked and restreaked on to fresh medium. Isolates were considered to be pure if colonies were similar in appearance, consisted of morphologically similar organisms, failed to grow on nutrient agar and yeast extract agar, and grew on NMS and AMS agar only when methane was present in the culture atmosphere. Ability to utilize methane was checked by analysing gas samples at intervals.

The two main problems encountered in isolation were the scavenging activities of amoebae (cross-contaminating and consuming colonies) and the contamination of methane-consuming colonies with barely visible colonies of actively motile, small Gram-negative rods which did not utilize methane.

\section{Properties}

General. All the organisms were strictly aerobic, catalase and oxidase-positive, Gram-negative bacteria, growing only on methane and methanol of the substrates tested (below). Methanol was extremely toxic to many strains when added to the medium, even at $0.01 \%(\mathrm{w} / \mathrm{v})$, and they only grew on methanol when incubated on slopes of NMS agar in sealed 51 . containers containing methanol vapour given off slowly from 4 or 5 slopes of uninoculated agar containing $0 . \mathrm{I} \%(\mathrm{w} / \mathrm{v})$ methanol. Other strains tolerated up to $\mathrm{I} \cdot 5 \%(\mathrm{w} / \mathrm{v})$ methanol in the medium. Formate, although oxidized by suspensions of organisms, was not utilized as a growth substrate, nor were other organic acids (gluconate, citrate, malate, acetate, fumarate, pyruvate and lactate), sugars and related compounds (glucose, mannose, fructose, arabinose, xylose, sucrose, maltose, cellobiose, lactose, glycerol, sorbitol and mannitol), and amino acids (L-glutamic acid, L-lysine, L-aspartic acid, L-serine, L-alanine, L-arginine, L-tryptophan and Casamino acids). Nutrient agar and yeast extract $(0.5 \% \mathrm{w} / \mathrm{v})$ agar inhibited the growth of all organisms in the presence of methane. All strains grew over a $\mathrm{pH}$ range of 5.8 to 7.4 and a $\mathrm{pH}$ value of 6.6 to 6.8 appeared to be the optimum for growth rate and yield.

The final composition of the mineral salts media routinely used was chosen to suit all strains. Concentrations of phosphates greater than $0.2 \%(w / v)$ and ammonium chloride greater than $0.05 \%(\mathrm{w} / \mathrm{v})$ inhibited many strains. Iron concentrations, as sequestered iron, were critical; a Io-fold increase or decrease of the concentration used diminished the growth rate of a number of strains. Calcium was essential and a trace element mixture was routinely included in the medium as some strains behave erratically in its absence.

All organisms were subcultured at 2-weekly intervals at $30^{\circ}$.

Nitrogen sources. Ammonium salts were used by all the organisms, nitrite and nitrate salts by the majority, and urea, casamino acids and yeast extract by some. All formed non-inhibitory concentrations of nitrite from ammonia, an activity previously recorded for methane-utilizers by Hutton \& ZoBell (1949). Organisms using nitrate reduced some to nitrite, but were unable to grow anaerobically on methane with nitrate as an alternative electron acceptor to oxygen. Nitrate appeared to be preferred to ammonium salts by these organisms as a nitrogen source, as reported by Leadbetter \& Foster (1958) for their organisms, but this proved to be an effect of $\mathrm{pH}$ change in the growing cultures. While the $\mathrm{pH}$ value in nitrate cultures remained around neutrality, in ammonium salts cultures it fell to 5.0 or lower and growth was partially inhibited. When $\mathrm{pH}$ value was controlled automatically by titration with $\mathrm{KOH}$, growth rates 
were similar with nitrate and ammonium salts and growth yields higher with ammonium salts.

No direct assay of nitrogen-fixing ability has been made, but all strains were screened for their ability to reduce acetylene to ethylene, a standard assay for nitrogenase (Dilworth, I966; Schöllhorn \& Burris, 1967). Only one organism actively reduced acetylene $(25 \%$ of that available compared with less than $\mathrm{I} \cdot 0 \%$ or none by the other organisms). This organism, strain 'Methylosinus trichosporium' PG was isolated from a culture originating from V.F. Coty (Coty, 1967), kindly provided by Professor J. R. Postgate.

Methane and methanol utilization. A comparison of the stoichiometry of methane and methanol utilization, and the efficiency with which they were converted into bacterial dry weight, was carried out on a number of strains. The two most efficient organisms were non-capsulate, non-slime-forming, did not normally form detectable lipid inclusions, and were not inhibited by methanol at the concentrations used. The following results apply to these two strains. Organisms and carbon dioxide were the only end-products of methane and methanol utilization detected. The stoichiometry of methane oxidation was similar when measured in batch cultures, in which all the methane had been consumed, and when sampled at hourly intervals in a culture growing exponentially in a closed, circulating atmosphere of methane and air (see Methods). Results are expressed in the following two equations:

$$
\begin{aligned}
& \text { (Methane) I } \mathrm{CH}_{4}+\mathrm{I} \cdot 0 \text { to I } \cdot \mathrm{I} \mathrm{O}_{2} \rightarrow 0.2 \text { to } 0.3 \mathrm{CO}_{2} \\
& \text { (Methanol) I } \mathrm{CH}_{3} \mathrm{OH}+\mathrm{I} \cdot 0 \text { to I } \cdot \mathrm{I} \mathrm{O}_{2} \rightarrow 0.5 \text { to } 0.6 \mathrm{CO}_{2} \text {. }
\end{aligned}
$$

The finding that more carbon dioxide was formed from methanol than from methane correlated with the bacterial dry weight yields, $0.4 \mathrm{~g}$. dry wt $/ \mathrm{I} \cdot 0 \mathrm{~g}$. methanol and $\mathrm{I} \cdot \mathrm{O}$ to $\mathrm{I} \cdot \mathrm{I}$ g. dry $\mathrm{wt} / \mathrm{I} \cdot \mathrm{O} \mathrm{g}$. methane. On a molar basis methanol yielded about $20 \%$ less dry weight organisms than did methane, implying that energy useful to the organisms is released in the initial oxidation of methane. Estimated carbon balances, based on the stoichiometry and bacterial dry weights obtained and assuming $47 \%$ of the bacterial dry weight is carbon (Johnson, 1967) were about $100 \%$ and suggested that carboncontaining products other than organisms and carbon dioxide were not formed under these cultured conditions.

Bacterial dry weights obtained with slime-forming strains were less than $\mathrm{I} \cdot 0 \mathrm{~g}$./ $\mathrm{I} \cdot \mathrm{Og}$. methane, and carbon dioxide production higher per mole of methane than that given above. Variations in the stoichiometry of methane utilization also occurred under nitrogen limitation and with non-growing bacterial suspensions. In the former case, oxygen consumption and carbon dioxide production were lower per mole of methane utilized and the organisms became packed with lipid inclusions, the major portion being identified as poly- $\beta$-hydroxybutyrate. In the latter case oxygen consumption and carbon dioxide production increased per mole of methane utilized.

The pattern of oxygen consumption and carbon dioxide production by organisms growing on methane reported here is very similar to that recorded by Brown et al. (1964) but not to that reported by Leadbetter \& Foster (1958). Their observation, 0.4 mole of $\mathrm{O}_{2}$ utilized/1 $\cdot 0$ mole of methane, seems impossibly low, especially on the assumption they make that 0.5 mole of $\mathrm{O}_{2}$ is required in the initial conversion of I mole methane to methanol.

The effects of ethane, ethanol and methanol on methane oxidation. Leadbetter \& 
Foster (1958) observed that ethane and ethanol, while not supporting growth, were oxidized by methane utilizers. Most of the methane utilizers studied by us behaved similarly, non-growing suspensions of bacteria oxidizing ethane or ethanol to acetaldehyde, as recorded for Methylococcus capsulatus (Patel, Hoare \& Taylor, 1969). One strain did not oxidize ethane but was inhibited by it, failing to oxidize methane, methanol or ethanol in its presence. A survey of the effects of methane, ethane, methanol and ethanol on the oxidation of each other revealed both stimulatory and inhibitory effects represented by the examples in Table I. Methane oxidation by all strains was inhibited to different degrees by ethane and frequently by methanol and by ethanol. The inhibitory effect of ethane on methane oxidation was reflected in the growth rates of methane-utilizers on Sahara natural gas (containing $7 \cdot 7 \% \mathrm{v} / \mathrm{v}$ ethane) which proved to be inferior to biologically produced methane (free of other hydrocarbons) as a substrate. Organisms either failed to grow, or had 25 to $50 \%$ longer generation times on Sahara natural gas than on ethane-free methane. Preliminary experiments revealed that $n$-propane and $n$-butane were at least as inhibitory as ethane.

\section{Table I. Oxidation of methane, methanol, ethane and ethanol (single and in pairs) by methane-utilizing bacteria}

Conical flasks $(25 \mathrm{ml}$.) contained $5 \mathrm{ml}$. suspensions of bacteria (equiv. dry wt, $3 \mathrm{mg} . / \mathrm{ml}$.) in NMS medium (see Methods) and were sealed with 'Suba-seal' caps through which substrate ( $45 \mu$ moles), in liquid or gas phase, was inserted by syringe. Ratio of air to gaseous hydrocarbons, volumetrically, was approximately 20:I (single hydrocarbon) or 20: I: I (two hydrocarbons); suspensions were shaken for $4 \mathrm{hr}$ at $30^{\circ}$ and gas and liquid samples were removed by syringe for analysis (see Methods). Samples from controls (flasks with no bacteria) were taken at the beginning and end of the experiment.

\begin{tabular}{|c|c|c|c|c|c|c|}
\hline \multirow[b]{2}{*}{ Strain } & \multirow[b]{2}{*}{ Substrate } & \multicolumn{5}{|c|}{$\begin{array}{l}\mu \text { moles of substrate oxidized alone or in the } \\
\text { presence of second substrate }\end{array}$} \\
\hline & & Alone & $+\mathrm{CH}_{4}$ & $+\mathrm{CH}_{3} \mathrm{OH}$ & $+\mathrm{C}_{2} \mathrm{H}_{6}$ & $+\mathrm{C}_{2} \mathrm{H}_{5} \mathrm{OH}$ \\
\hline 'Methylomonas agile' А 30 & $\begin{array}{l}\mathrm{CH}_{4} \\
\mathrm{CH}_{3} \mathrm{OH} \\
\mathrm{C}_{2} \mathrm{H}_{6} \\
\mathrm{C}_{2} \mathrm{H}_{5} \mathrm{OH}\end{array}$ & $\begin{array}{r}13 \\
23 \\
0 \\
12\end{array}$ & $\begin{array}{r}- \\
21 \\
0 \\
16\end{array}$ & $\begin{array}{r}9 \\
5 \\
12\end{array}$ & $\begin{array}{r}0 \\
19 \\
\text { NT }\end{array}$ & $\begin{array}{r}\mathbf{I} \\
2 \mathbf{I} \\
\mathrm{NT} \\
-\end{array}$ \\
\hline 'Methylococcus capsulatus' MC & $\begin{array}{l}\mathrm{CH}_{4} \\
\mathrm{CH}_{3} \mathrm{OH} \\
\mathrm{C}_{2} \mathrm{H}_{6} \\
\mathrm{C}_{2} \mathrm{H}_{5} \mathrm{OH}\end{array}$ & $\begin{array}{r}26 \\
31 \\
5 \\
27\end{array}$ & $\begin{array}{l}- \\
23 \\
12 \\
28\end{array}$ & $\begin{array}{l}\frac{15}{12} \\
23\end{array}$ & $\begin{array}{l}2 \mathrm{I} \\
28 \\
\overline{\mathrm{NT}}\end{array}$ & $\begin{array}{r}\text { Io } \\
\text { NT } \\
- \\
-\end{array}$ \\
\hline $\begin{array}{l}\text { 'Methylosinus trichosporium' } \\
\text { ОВ } 3 \text { В }\end{array}$ & $\begin{array}{l}\mathrm{CH}_{4} \\
\mathrm{CH}_{3} \mathrm{OH} \\
\mathrm{C}_{2} \mathrm{H}_{6} \\
\mathrm{C}_{2} \mathrm{H}_{5} \mathrm{OH}\end{array}$ & $\begin{array}{l}42 \\
39 \\
13 \\
42\end{array}$ & $\begin{array}{l}- \\
36 \\
10 \\
42\end{array}$ & $\frac{3}{16}$ & $\frac{{ }^{7}}{\mathrm{NT}}$ & $\begin{array}{r}8 \\
42 \\
\mathrm{NT} \\
-\end{array}$ \\
\hline 'Methylomonas albus' BG 8 & $\begin{array}{l}\mathrm{CH}_{4} \\
\mathrm{CH}_{3} \mathrm{OH} \\
\mathrm{C}_{2} \mathrm{H}_{6} \\
\mathrm{C}_{2} \mathrm{H}_{5} \mathrm{OH}\end{array}$ & $\begin{array}{r}17 \\
32 \\
8 \\
30\end{array}$ & $\begin{array}{l}- \\
32 \\
11 \\
31\end{array}$ & $\frac{19}{16}$ & $\frac{5}{32}$ & $\begin{array}{r}5 \\
28 \\
N T \\
-\end{array}$ \\
\hline
\end{tabular}

Effect of ammonium ion on methane oxidation. In cultures containing ammonium chloride above $0.05 \%(\mathrm{w} / \mathrm{v})$ growth rates of many organisms were lowered. The rate of methane oxidation by suspensions of bacteria (Table 2) decreased with increasing ammonium ion concentration. Strains differed in their sensitivity towards ammonium ion; the examples given in Table 2 represent the behaviour of most organisms, some 
were less and others more sensitive to ammonium ion. The possibility that nitrite (formed by all strains) might be accumulating to inhibitory levels was discounted, as a concentration Io-fold greater than the maximum detected did not affect either methane oxidation or growth rates when added to AMS and NMS media. These results suggest the possibility of ammonium ion being an analogue of methane and perhaps a competitive inhibitor of its oxidation.

\section{Table 2. Ammonium ion inhibition of methane oxidation by strain 'Methylosinus trichosporium' $O B{ }_{3 B}$}

Conical flasks $(25 \mathrm{ml}$.) contained $5 \mathrm{ml}$. suspensions of bacteria (grown on NMS medium equiv. dry wt, $3 \mathrm{mg}$./ml.) in AMS medium (see Methods) containing different concentrations of ammonium chloride, and were sealed with 'Suba-seal' caps through which methane ( $45 \mu$ moles) was inserted by syringe. Suspensions were shaken for $4 \mathrm{hr}$ at $30^{\circ}$ and gas and liquid samples were withdrawn by syringe for analysis of methane and nitrite content (see Methods). Control, uninoculated flasks, were sampled at the beginning and end of the experiment.

$\begin{gathered}\text { Ammonium } \\ \text { chloride } \\ (\%, w / v)\end{gathered}$
0
0.005
0.05
0.1
0.5

$\begin{array}{cc}\begin{array}{c}\text { Methane } \\ \text { oxidized } \\ (\mu \text { moles })\end{array} & \begin{array}{c}\text { Nitrite } \\ \text { formed } \\ (\mu \text { moles })\end{array} \\ 30 & 0 \\ 28 & 0 \cdot 2 \\ 22 & 0 \cdot 7 \\ 17 & \text { Trace } \\ 2 & \text { Trace }\end{array}$

Similar results were obtained with equivalent amounts of ammonium ion as ammonium sulphate.

Morphology. Strains differed in morphology; rods, cocci, vibrioid and pear-shaped organisms, of various sizes and dimensions, were observed, some possessing capsules and flagella. Many formed resting stages; three distinct types were detected, exospores and two types of cyst, one of which was morphologically similar to those formed by Azotobacter species. All were desiccation-resistant (viable after 3 days air-drying on glass slide), the exospores being also heat-resistant $\left(85^{\circ}\right.$ for $15 \mathrm{~min}$.). A fourth type of cell resembling an immature Azotobacter-type cyst was formed by some strains and was considered to be a resting stage in that such organisms survived the absence of methane but not desiccation. Resting stages and their properties are described in another report (Whittenbury, Davies \& Davey, 1970).

Fine structure. All strains possessed complex membranous organelles similar in complexity to those found in nitrifying and photosynthetic bacteria. Two basic membrane arrangements were observed, a system of paired membranes running throughout the bacterium or aggregated at its periphery (type I), and a series of bundles composed of disc-shaped membrane vesicles distributed throughout the cell (type II). These structures are described in detail in another report (Davies \& Whittenbury, 1970).

\section{Classification}

Attempts at a formal classification are premature at this stage; conventional tests provided little information of differential value. However, variation in morphology, fine structure and type of resting stage formed, indicated fundamental differences between strains and served as a basis for a provisional classification (Table 3) of the organisms into two vibrioid groups, 'Methylosinus' and 'Methylocystis', and three 
$\mathrm{rod} /$ coccoid groups, 'Methylomonas', 'Methylobacter' and 'Methylococcus'. These groups were subdivided on the basis of various characteristics (Table 4).

Group 'Methylosinus' (subgroups 'trichosporium' and 'sporium'). In the non-sporing stage the organisms were generally rod-shaped (Pl. I, fig. I), but occasionally of bizarre form (Pl. I, fig. 7), and possessed a polar tuft of flagella (Pl. 3, fig. 3I, 32). Rosettes (Pl. I, fig. 4, 5) were frequently formed, the organisms being anchored at their non-flagellated poles by 'holdfast' material discernible microscopically (P1. I, fig. 4) and stained by the polysaccharide stain of Hotchkiss (1948). The capsules formed by these organisms did not respond to the polysaccharide stain. Exospores (P1. I, fig. I, 2), which were heat-resistant, were budded off the non-flagellated poles of the organisms which assumed a pear-shape ('Methylosinus trichosporium') or vibrio-shape ('Methylosinus sporium') (Pl. I, fig. I, 2), at the onset of sporulation. All strains possessed a type I membranous system and divided at 5 to $6 \mathrm{hr}$ under optimal growth conditions. Main differences between the two subgroups were cell-shape and size, spore morphology ('Methylosinus trichosporium' spores were capsulated) and pigment production.

Table 3. Properties characterizing groups of methane-utilizing bacteria

\begin{tabular}{|c|c|c|c|c|c|}
\hline Group & Resting stage & $\begin{array}{c}\text { Membrane } \\
\text { type }\end{array}$ & Morphology & $\begin{array}{l}\text { Rosettes } \\
\text { formed }\end{array}$ & $\begin{array}{l}\text { Colloquial } \\
\text { description }\end{array}$ \\
\hline 'Methylosinus' & Exospore & I & $\begin{array}{l}\text { Rod or pear- } \\
\text { shaped cells }\end{array}$ & + & $\begin{array}{l}\text { Vibrioid } \\
\text { groups }\end{array}$ \\
\hline 'Methylocystis' & 'Lipid' cyst & I & $\begin{array}{l}\text { Rod or vibrioid } \\
\text { cell }\end{array}$ & + & \\
\hline 'Methylomonas' & $\begin{array}{l}\text { 'Immature* Azoto- } \\
\text { bacter-type' cyst }\end{array}$ & II & Rod & - & $\begin{array}{l}\text { Rod/coccoid } \\
\text { groups }\end{array}$ \\
\hline 'Methylobacter' & $\begin{array}{l}\text { Azotobacter-type } \\
\text { cyst }\end{array}$ & II & Rod & - & \\
\hline 'Methylococcus' & $\begin{array}{l}\text { 'Immature* Azoto- } \\
\text { bacter-type' cyst }\end{array}$ & II & Coccus & - & \\
\hline
\end{tabular}

Group 'Methylocystis' (subgroup 'parvus'). Only one strain was isolated (Pl. I, fig. 3). It was similar in fine structure and rosetting habit (Pl. I, fig. 6) to 'Methylosinus' strains, but differed from them in being non-motile and non-spore-forming. A cyst, however, was formed which was desiccation but not heat-resistant.

Group 'Methylomonas' (subgroups 'methanica', 'albus', 'streptobacterium', 'agile', 'rubrum' and 'rosaceus'). All the organisms were rod-shaped (P1. I, fig. 8 to I3) and possessed a type II membranous system. Many were capsulated (e.g. Pl. 3, fig. 26). Motile strains were polarly flagellated (Pl. 3, fig. 33, 34). In all subgroups some strains formed a resting stage (similar to immature azotobacter-type cysts) which was not desiccation resistant but survived the absence of methane for 4 to 5 weeks; vegetative cells only survived 3 to 4 days. The failure to detect the presence of desiccation-resistant forms in cultures of these organisms may be a result of inadequate cultural conditions.

Subgroup 'methanica' strains (P1. I, fig. 13) were identified as Pseudomonas methanica as described by Leadbetter \& Foster (1958). They were isolated from samples from all areas examined and were the most commonly encountered methane-utilizing bacterium. On isolation colonies were both yellow-ochre and pink-coloured, the yellow-ochre colour disappearing as the culture aged and not appearing at all after 


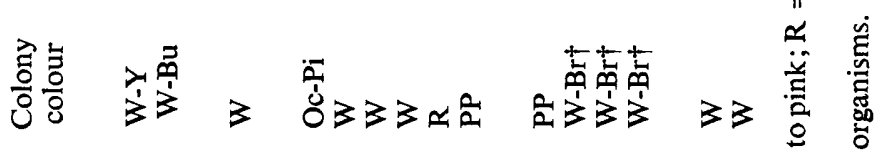

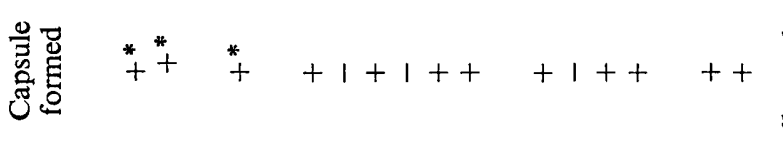

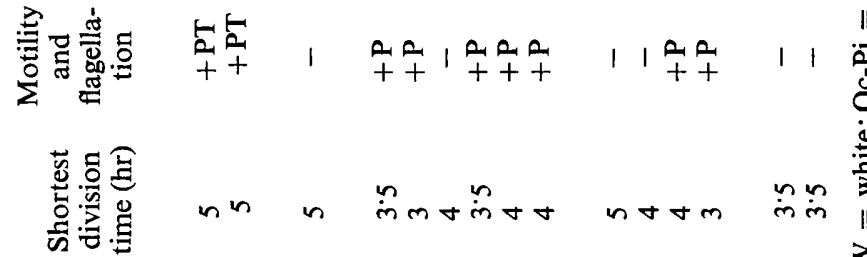

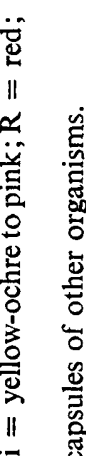

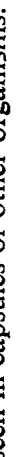

$\frac{\sqrt{5}}{0}$

芯

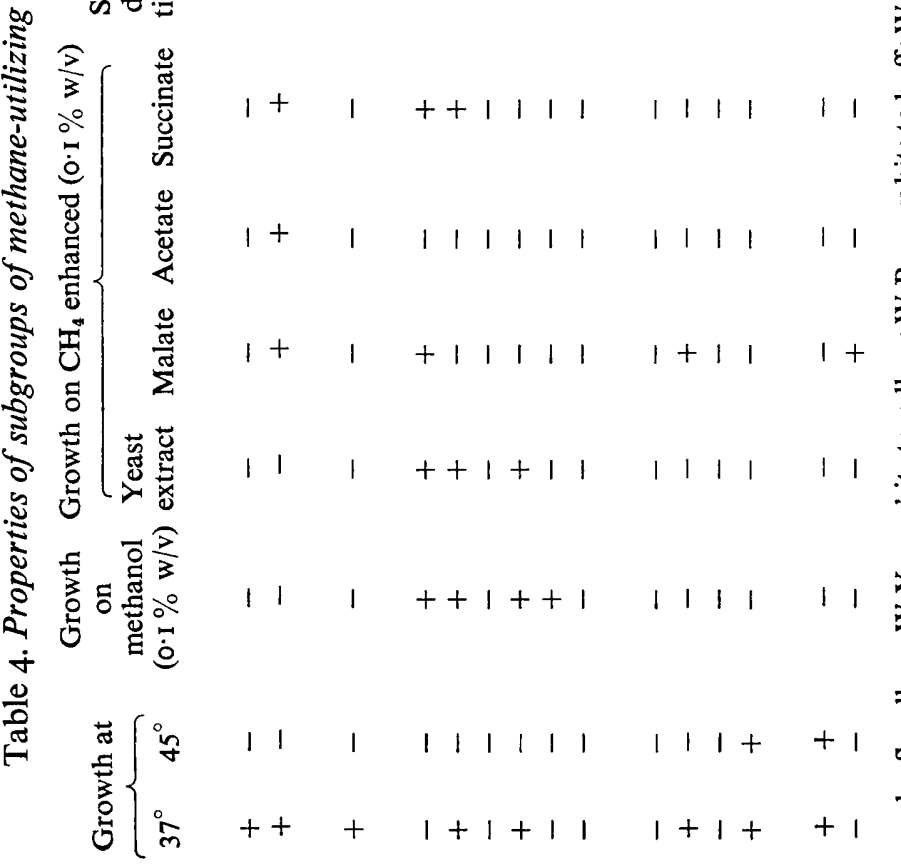

品

苛

용ㅇ

产营要

느웡

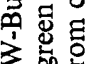

$\sum_{\infty}^{\infty}$

을

ญํ:중

总

3 题

II

文它皆

घi 11 o on

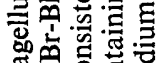

世纪

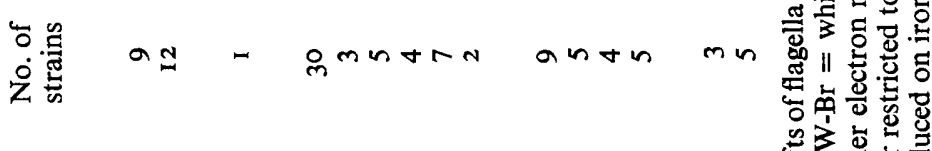

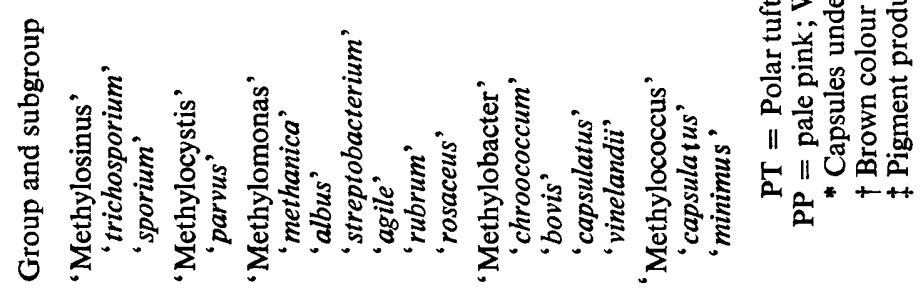


several subcultures. Carotenoid spectra were similar to those recorded by Leadbetter \& Foster for P. methanica; no strain has yet lost its pigmentation as did some of Leadbetter \& Foster's organisms. Colony texture varied with the nitrogen source. In agar medium containing ammonium salts, colonies were tough and difficult to remove, the organisms being embedded in slime ( $\mathrm{Pl} .3$, fig. 23), and in liquid medium organisms grew in clumps which were difficult to break up. When nitrate was used, a slimy variant colony appeared on agar, easy to subculture, and after two or three subcultures became dominant, but colony type reverted to the tough form on subculture back to ammonium salts-containing agar media. In liquid media containing nitrate, copious amounts of slime were found, but the organisms were dispersed. Similar growth behaviour was observed by Leadbetter \& Foster (1958) for their pink strains of $P$. methanica.

In static liquid cultures, the 'methanica' strains formed pellicles; most of the other subgroups did not.

Group 'Methylobacter' (subgroups 'chroococcum', 'bovis', 'capsulatus' and 'vinelandii'). Most strains were rod-shaped at all stages in their growth cycle, many resembling 'Methylomonas' strains morphologically. Some, however, were remarkably similar to the large-cell-forming species of Azotobacter, changing from rod form to coccal and intermediate forms and back to rod form (Pl. 2, fig. I4 to I7). In coccal form, tetrads were produced (Pl. 2, fig. I8). The largest organism (Pl. 2, fig. I9) measured $4.5 \mu \mathrm{m} . \times 3.2 \mu \mathrm{m}$. but was fragile and burst easily under pressure applied by thumb to a coverslip on a glass slide ( $\mathrm{Pl}$. 2, fig. 20). The similarity of all 'Methylobacter' strains to Azotobacter species extended to slime and capsule formation (Pl. 3, fig. 24, 28, 29), formation of desiccation-resistant cysts (e.g. Pl. 3, fig. 30) and production of pigment on cyst formation. None, however, grew in nitrogen-free liquid media and no Azotobacter species in the National Collection of Industrial Bacteria (Aberdeen) oxidized methane.

When isolated, all the large organisms of the 'chroococcum' subgroup formed multiple-bodied cysts but on continued subculture ceased to do so and diminished in size, finally dying out after 8 to 12 months. No medium has yet been devised which was able to maintain them for more than 3 to 4 weeks in the form in which they were isolated. The remaining strains of 'Methylobacter' were more robust than 'chroococcum' strains and were easily maintained. They have continued to form single and multiple-bodied cysts for 2 years. Subgroup 'vinelandii' strains were the most commonly isolated methane utilizers from enrichments at 37 to $55^{\circ}$. The first of the subgroup 'bovis' strains was isolated from a cow's mouth.

All 'Methylobacter' strains possessed a type II membranous system. Some were polarly flagellated. Under optimal growth conditions, the generation time was about $4 \mathrm{hr}$ for all strains.

Organisms were divided into subgroups on the basis of morphology, pigment, motility and growth temperature.

Group 'Methylococcus' (subgroups 'capsulatus' and 'minimus'). These organisms were non-motile cocci (Pl. 2, fig. 2I, 22) possessing capsules (e.g. Pl. 3, fig. 27) and a type II membranous system. Both types formed resting stages similar to immature azotobacter cysts. Shortest generation times were 3.5 to $4 \mathrm{hr}$. Organisms were divided into subgroups on morphology ('Methylococcus minimus' strains formed chains) and ability to grow at 37 and $45^{\circ}$. Subgroup 'capsulatus' includes a strain of Methylococcus capsulatus isolated by Foster \& Davis (1966). 


\section{Comparison of isolates with previously described species}

Some strains were considered to be identical with the previously described methaneutilizing species, Pseudomonas methanica (Leadbetter \& Foster, 1958) and Methylococcus capsulatus (Foster \& Davis, 1966). None were identified as Methanomonas methanooxidans (Brown et al. 1964). The 'Methylosinus' strains may be similar to Pseudomonas methanitrificans (Coty, 1967), as one strain was isolated from a culture originating from Coty. Other strains described here may have been encountered by Leadbetter \& Foster (1958), particularly the 'Methylobacter vinelandii' strains, which seem very similar to the organisms isolated by Leadbetter \& Foster from enrichments at $37^{\circ}$.

\section{CONCLUSION}

Methane-utilizing bacteria were found to be a more diverse group of organisms than was implied in earlier reports. All utilized only methane or methanol of the substrates tested and all possessed other unusual properties (a complex fine structure and the ability to form cysts and exospores). As this report is only an introduction to the organisms, no attempt will be made to speculate on the significance of their unusual properties. A curious result of this investigation was the failure to isolate any Grampositive organism, bacterium or yeast, able to utilize or oxidize methane. In this laboratory $\mathrm{Mr} \mathrm{A}$. G. McLee isolated a variety of Gram-positive bacteria which utilized $\mathrm{C}_{2}$ to $\mathrm{C}_{4} n$-alkanes, but did not oxidize methane.

This work was partly financed by a Science Research Council grant to Professor J. F. Wilkinson.

\section{REFERENCES}

Brown, L. R., Strawinski, R. J. \& MCCleskey, C. S. (1964). The isolation and characterization of Methanomonas methanooxidans Brown and Strawinski. Canadian Journal of Microbiology 1o, $79 \mathrm{I}$.

CoTy, V. F. (1967). Atmospheric nitrogen fixation by hydrocarbon-oxidizing bacteria. Biotechnology and Bioengineering 9, 25.

Davies, S. L. \& Whittenbury, R. (1970). Fine structure of methane and other hydrocarbonutilizing bacteria. Journal of General Microbiology 6r, 227.

DilworTh, M. J. (1966). Acetylene reduction by nitrogen-fixing preparations from Clostridium pasteurianum. Biochimica et Biophysica Acta 127, 285.

Dworkin, M. \& Foster, J. W. (1956). Studies on Pseudomonas methanica (Söhngen) nov. comb. Journal of Bacteriology 72, 646.

Foster, J. W. \& DAVIs, R. H. (1966). A methane-dependent coccus, with notes on classification and nomenclature of obligate, methane-utilizing bacteria. Journal of Bacteriology 91, 1924.

Hoтchкiss, R. D. (1948). A microchemical reaction resulting in the staining of polysaccharide structures in fixed tissue preparations. Archives of Biochemistry 16, I3I.

Hutton, W. E. \& ZoBell, C. E. (1949). The occurrence and characteristics of methane-oxidizing bacteria in marine sediments. Journal of Bacteriology $\mathbf{5 8 , 4 6 3 .}$

Johnson, M. J. (1967). Growth of microbial cells on hydrocarbons. Science, New York $155,1515$.

LAW, J. H. \& SLEPECKY, R. A. (196r). Assay of poly- $\beta$-hydroxybutyric acid. Journal of Bacteriology 82, 33 .

LeAdbetter, E. R. \& Foster, J. W. (1958). Studies on some methane utilizing bacteria. Archiv für Mikrobiologie 30, $9 \mathrm{I}$.

Patel, R., Hoare, D. S. \& Taylor, B. F. (1969). Biochemical basis for the obligate C-I dependence of Methylococcus capsulatus. Bacteriological Proceedings 128.

Perry, J. J. (1968). Substrate specificity in hydrocarbon utilizing micro-organisms. Antonie van Leeuwenhoek 34, 27.

PFennig, N. (1962). Beobachtungen über das Schwärmen von Chromatium okenii. Archiv für Mikrobiologie 42, 90 . 
RAKESTRAW, N. W. (1936). The occurrence and significance of nitrite in the sea. Biological Bulletin Marine Biological Laboratory, Woods Hole, Mass. 7I, I33.

SCHÖLlhorN, R. \& Burris, R. H. (1967). Reduction of azide by the $\mathrm{N}_{2}$-fixing enzyme system. Proceedings of the National Academy of Sciences of the United States of America 57, 1317.

VARY, P. S. \& JOHNSON, M. J. (1967). Cell yields of bacteria grown on methane. Applied Microbiology I5, 1473 .

Whittenbury, R., Davies, S. L. \& Davey, J. F. (1970). Exospores and cysts formed by methaneutilizing bacteria. Journal of General Microbiology 6r, 219.

\section{EXPLANATION OF PLATES}

\section{Plate I}

Phase-contrast micrographs, magnification $\times 1900$. The bar (fig. I) equals $5 \mu \mathrm{m}$.

Fig. I. Indian ink preparation of 'Methylosinus trichosporium' showing a pair of vegetative organisms (top right) and sporulating organisms budding off spores (centre). Spores possess larger capsule than sporulating or vegetative organisms.

Fig. 2. 'Methylosinus sporium' preparation showing occasional vegetative cell and many sporulating organisms (vibrioid) and spores.

Fig. 3. 'Methylocystis parvus' vegetative organisms.

Fig. 4. 'Methylosinus trichosporium' rosette. Organisms anchored by visible 'holdfast' material.

Fig. 5. 'Methylosinus sporium' rosettes made up of vegetative and sporulating organisms.

Fig. 6. 'Methylocystis parvus' rosette of organisms.

Fig. 7. 'Methylosinus trichosporium' malformed vegetative organism.

Fig. 8. 'Methylomonas rosaceus' organisms.

Fig. 9. 'Methylomonas rubrum' organisms.

Fig. 10. 'Methylomonas' organisms.

Fig. II. 'Methylomonas streptobacterium' organisms.

Fig. 12. 'Methylomonas agile' organisms.

Fig. 13. 'Methylomonas methanica' organisms.

Plate 2

Phase-contrast micrographs, magnification $\times 1900$. The bar (fig. 15) equals $5 \mu \mathrm{m}$.

Fig. 14. 'Methylobacter chroococcum' strain HP organisms.

Fig. I 5, 16. 'Methylobacter chroococcum' strain P in coccal form and rod and rod-coccal form.

Fig. 17. 'Methylobacter chroococcum' strain F organisms.

Fig. 18. 'Methylobacter chroococcum' strain G in filamentous form.

Fig. 19. 'Methylobacter chroococcum' strain L organisms.

Fig. 20. 'Methylobacter chroococcum' strain L lysing organisms.

Fig. 21. Methylococcus capsulatus organisms.

Fig. 22. 'Methylococcus minimus' organisms.

\section{Plate 3}

Fig. 23 to 29. Phase-contrast micrographs of Indian ink preparations. Fig. 31 to 34 . Brightfield flagella stain preparations. All micrographs magnification $\times$ I900. The bar (fig. 25) equals $5 \mu \mathrm{m}$.

Fig. 23. 'Methylomonas methanica' organisms embedded in slime.

Fig. 24. Capsules of 'Methylobacter chrooccccum' strain P organisms.

Fig. 25. Capsules of Methylobacter capsulatus organisms.

Fig. 26. Capsules of 'Methylomonas streptobacterium' organisms.

Fig. 27. Capsules of 'Methylococcus minimus' organisms.

Fig. 28. Capsules of 'Methylobacter chroococcum' strain L organisms.

Fig. 29. Capsules of 'Methylobacter chroococcum' strain HP organisms. 
Fig. 30. Preparation of 'Methylobacter vinelandii' showing immature cysts (large dark cells) and mature cysts (refractile cells) and vegetative rods.

Fig. 31. 'Methylosinus trichosporium', polar tuft of flagella.

Fig. 32. 'Methylosinus sporium', polar tuft of flagella.

Fig. 33. 'Methylomonas albus' single polar flagellum.

Fig. 34. 'Methylomonas methanica' single polar flagellum. 

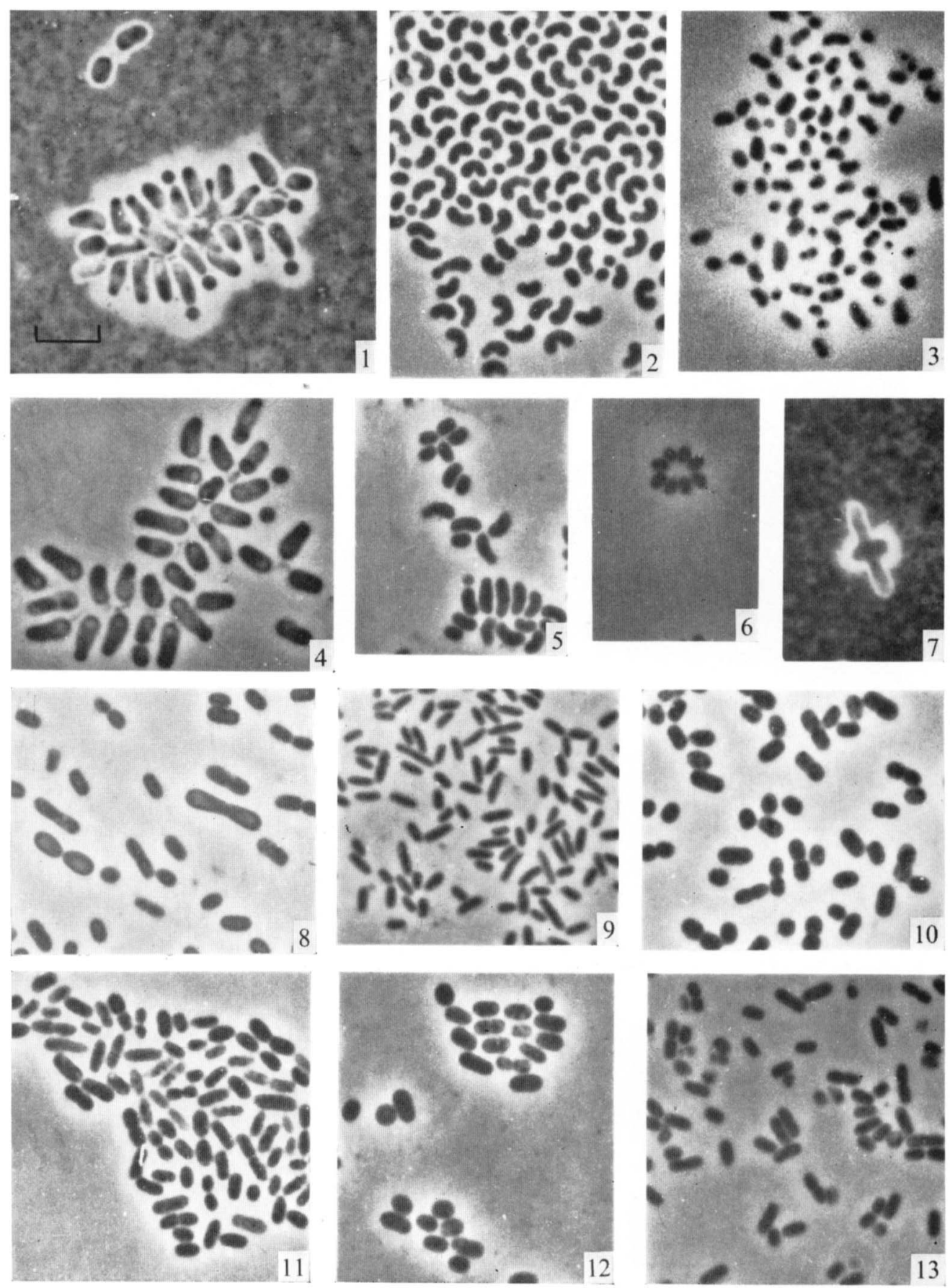

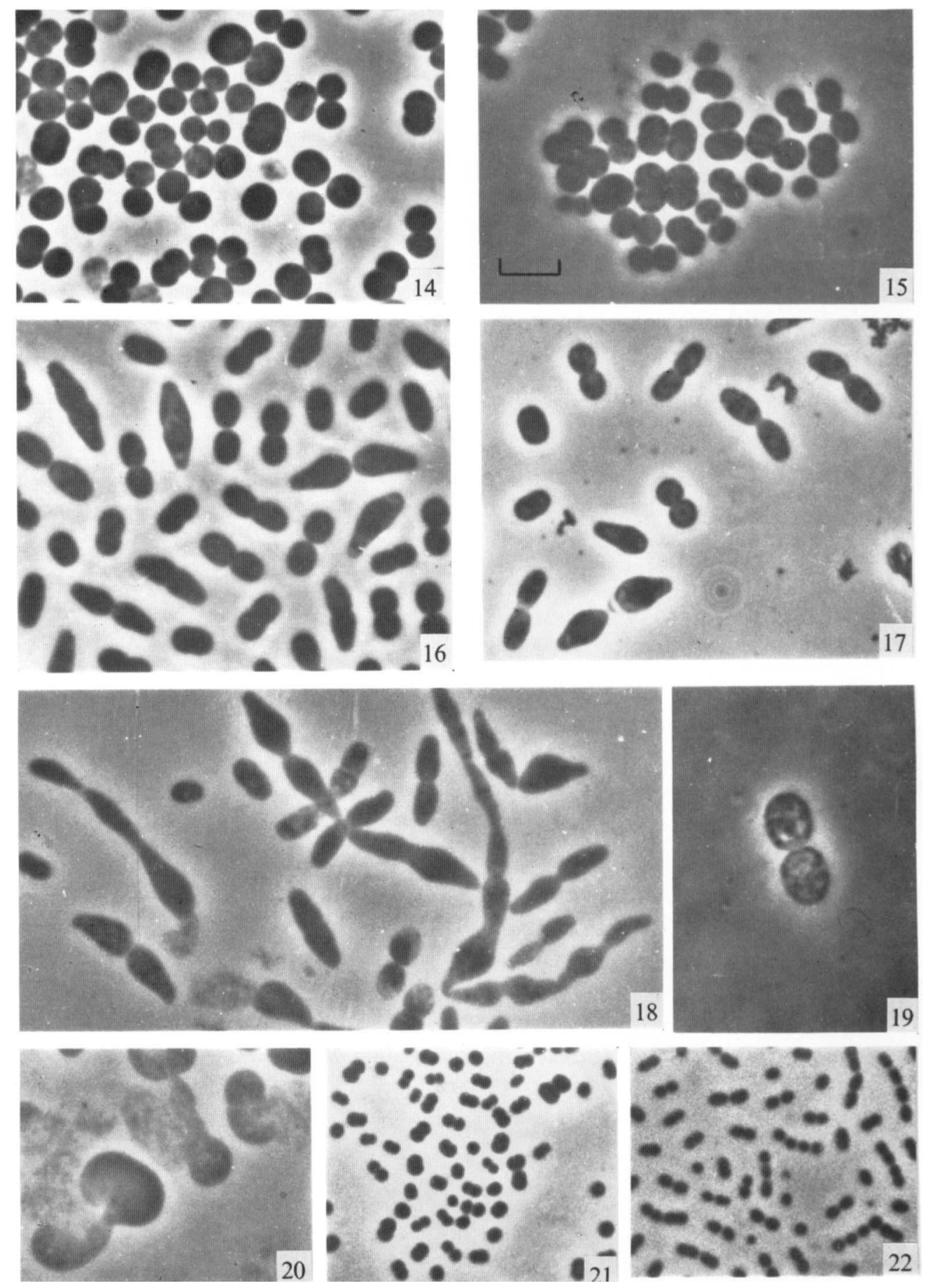

R. WHITTENBURY, K. C. PHILLIPS AND J. F. WILKINSON 
Journal of General Microbiology, Vol. 6I, No. 2

Plate 3
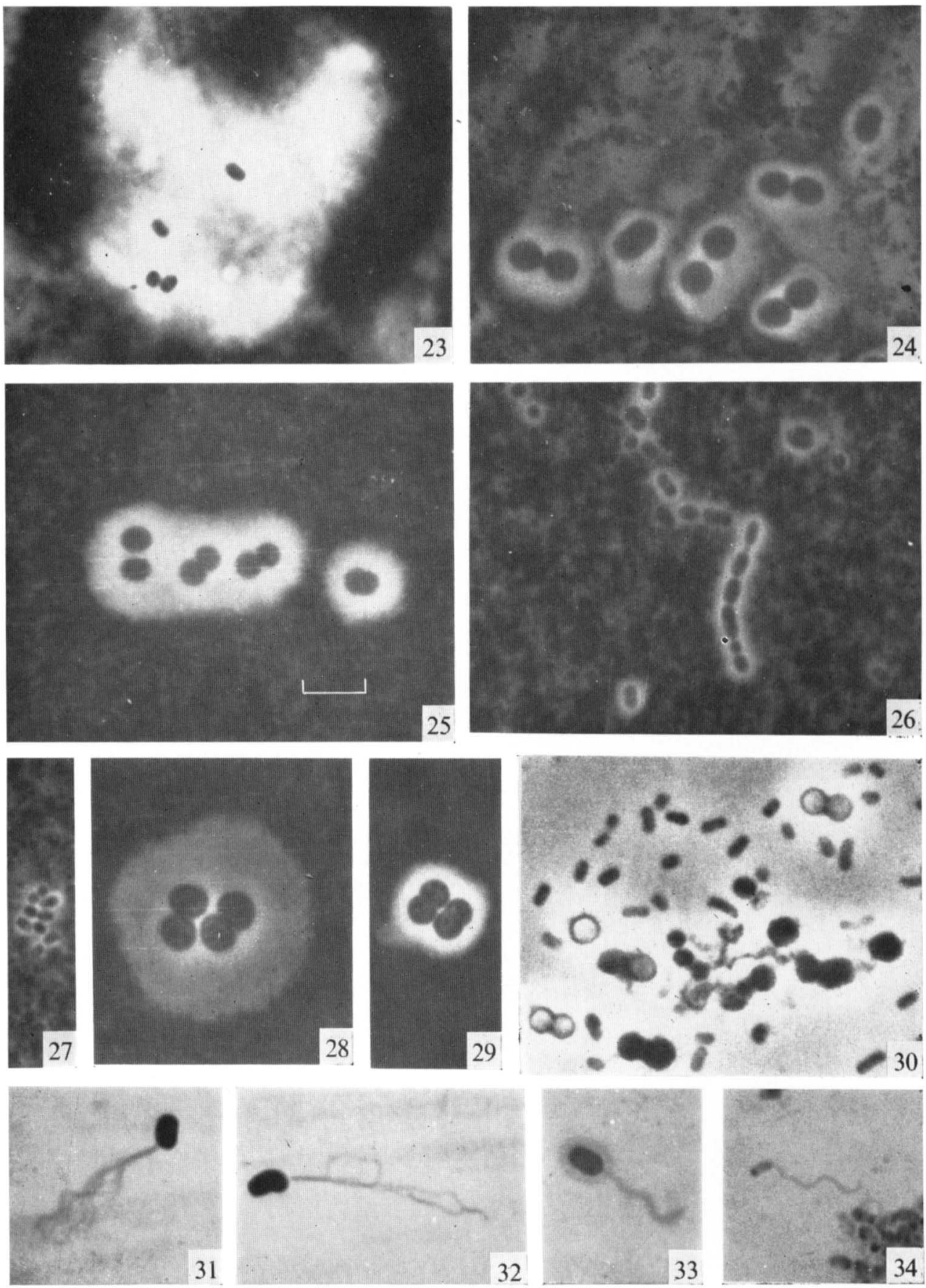

R. WHITTENBURY, K. C. PHILLIPS AND J. F. WILKINSON 